\title{
KEDISIPLINAN BELAJAR TERHADAP SELF-EFFICACY PESERTA DIDIK
}

\section{DISIPLINE OF LEARNING OF TOWARDS AND THE SELF-EFFICACY OF LEARNERS}

\author{
Z Nisa1a, $^{1}$ Abdurakhman' ${ }^{1}$, dan LO Amril ${ }^{2}$ \\ ${ }^{1}$ Program Studi Manajemen Pendidikan Islam, Fakultas Keguruan dan Ilmu Pendidikan, \\ Universitas Djuanda Bogor, Jl. Tol Ciawi No. 1 Kotak Pos 35 Ciawi Bogor 16720 \\ 2 Program Studi Pendidikan Guru Sekolah Dasar, Fakultas Keguruan dan Ilmu Pendidikan, \\ Universitas Djuanda Bogor, Jl. Tol Ciawi No. 1 Kotak Pos 35 Ciawi Bogor 16720 \\ a Korespondensi: Zaimatun Nisa, Email: nisazaima21@gmail.com \\ (Diterima: 03-12-2018; Ditelaah: 05-01-2019; Disetujui: 15-02-2019)
}

\begin{abstract}
This purpose of this study to determine whether or not the influence of learning discipline against self-efficacy learners. This study use quatitative approach which is functional relationship to know whether or not the influence of independent variables is the discipline of learning variables are dependent variable self-efficacy. Sample is the study 81 learners from 115 learners determined using Slovin formula calculation. Techniques of data collection using observation, questionnaures, documentation. The results showed the correlation between discipline learning participants (X) with self-efficacy learners (Y) obtained value of $r_{\text {count }}=0.668$ and the $r_{\text {table }}$ for 81 is 0.216 at the $5 \%$ significant level. This $\mathrm{r}_{\text {count }}>\mathrm{r}_{\text {table }}(0.668>0.216)$ then $\mathrm{H}_{0}$ rejected wich means there is a significant correlation between the discipline of learning towards self-efficacy learners. The significance of regression equation with $\mathrm{F}_{\text {count }}=63.535$ and $\mathrm{F}_{\text {table with dfreg }}=1$ dfres $=79$ is 3.96 at $5 \%$ level then $\mathrm{F}_{\text {count }}>\mathrm{F}_{\text {table }}$ hence $\mathrm{H}_{0}$ is rejected means there is significant influence between learning discipline with self-efficacy learners. The result of coefficient of determination $\mathrm{R}_{2}=$ 0.446 indicating the existence of $4.46 \%$ learners discipline influence student self-efficacy, the rest $55.4 \%$ influenced by other factor not analyzed in this reserch.
\end{abstract}

Keywords: discipline, learning, self-efficacy.

\section{ABSTRAK}

Penelitian ini bertujuan untuk mengetahui ada atau tidak adanya pengaruh antara kedisiplinan belajar terhadap self-efficacy peserta didik. Penelitian ini menggunakan pendekatan kuantitatif yang bersifat hubungan fungsional untuk mengetahui ada atau tidaknya pengaruh vaiabel bebas yaitu variabel kedisiplinan belajar terhadap variabel terikat yaitu variabel self-efficacy. Sample pada penelitian ini 81 peserta didik dari 115 peserta didik yang ditentukan dengan meggunakan perhitungan rumus Slovin. Teknik pengambilan data menggunakan observasi, angket, dokumentasi. Hasil penelitian menunjukan korelasi antara kedisiplinan belajar peserta didik (X) dengan self-efficacy peserta didik (Y) diperoleh nilai sebesar $r_{\text {hitung }}=0.668$ dan $r_{\text {tabel }}$ untuk 81 adalah 0.216 pada taraf signifikan $5 \%$ dengan demikian $r_{\text {hitung }}>r_{\text {tabel }}(0.668>0.216)$ maka $\mathrm{H}_{0}$ ditolak yang artinya terdapat korelasi yang signifikan antara kedisiplinan belajar peserta didik terhadap self-efficacy peserta didik. Signifikansi persamaan regresi dengan hasil nilai $\mathrm{F}_{\text {hitung }}=63.535$ dan $\mathrm{F}_{\text {tabel }}$ dengan dfreg $=1$ dfres $=79$ adalah 3.96 pada taraf $5 \%$ maka $\mathrm{F}_{\text {hitung }}>\mathrm{F}_{\text {tabel }}$ dengan demikian $\mathrm{H}_{0}$ ditolak yang berarti terdapat pengaruh yang signifikan antara kedisiplinan belajar terhadap self-efficacy peserta didik. Hasil koefisien determinasi $\mathrm{R}^{2}=0.446$ yang menunjukan adanya $44.6 \%$ kedisiplinan belajar peserta didik mempengaruhi self-efficacy 
peserta didik, sisanya 55,4\% dipengaruhi oleh faktor lainnya yang tidak dianalisa pada penelitian ini.

Kata kunci: belajar, kedisiplinan, self-efficacy.

Nisa, Z., Abdurakhman, O., \& Amril, L. O. (2019). Kedisiplinan Belajar dan Self-Efficacy Peserta Didik. Tadbir Muwahhid, 3(1), 68-82.

\section{PENDAHULUAN}

Self-efficacy (Keyakinan atau rasa percaya diri) pada dasarnya peserta didik memiliki kemampuan diri dalam belajar yang tentunya sangat berpengaruh pada proses pembelajaran seperti kemampuan dalam mengerjakan tugas yang dibebankan kapadanya, kemampuan dalam menyelesaikan tugas maupun kemampuan dalam memecahkan masalah, Peserta didik yang memiliki kemampuan diri terlihat lebih mampu dalam mengahadapi permasalahan-permasalahan, lebih terlihat percaya diri, yakin akan dirinya sendiri pada kehidupan sehari-hari baik dilingkungan sekolah maupun diluar lingkungan sekolah. Akan tetapi ada pula peserta didik yang tidak yakin dengan kemampuan yang dimilikinya. Adapun peserta didik yang memiliki kemampuan diri rendah mereka memiliki ciri yaitu: peserta didik cenderung menghindari tugas, peserta didik selalu menganggap tugas yang sulit sebagai ancaman bagi dirinya, peserta didik lebih percaya akan kemampuan orang lain dibandingkan kemampuan yang dimilikinya, ketika mengalami kegagalan akan sulit bangkit dari kegagalan tersebut dan tidak berpikir akan jalan keluar dari permasalahan yang dihadapinya.

Dalam penelitian ini pengertian selfefficacy yang juga dikemukakan oleh Albert Bandura (Bandura, 1994) Bahwa kemampuan diri atau self-efficacy dapat berhubungan dengan kedisiplinan belajar peserta didik. Menurut penelitian yang dikemukakan oleh munawaroh bahwa semakin tinggi tingkat kedisiplinan belajar peserta didik maka self-efficacy yang dimiliki peserta didik juga semakin tinggi (Munawaoh, 2017). Oleh sebab itu kedisiplinan merupakan saah satu faktor yang memiliki hubungan dengan tinggi rendahnya self-efficacy peserta didik. Dengan adanya kedisiplinan belajar yang dimiliki akan membuat peserta didik lebih terlatih dalam melakukan pekerjaan yang baik dan dapat mengatur setiap tindakannya sehingga peserta didik akan taat pada peraturan. Kedisiplinan belajar sangatlah dibutuhkan dalam proses pembelajaran karena tanpa adanya kesadaran diri dalam menaati peraturan akan membuat pembelajaran tidak efektif dan juga tidak efisien. Kedisiplinan belajar yang dilatih secara terus-menerus akan melahirkan peserta didik yang bertanggung jawab dengan apa yang telah ia lakukan dan siap menaati peraturan. Kedisiplinan belajar pula dapat menumbuhkan pada peserta didik yang mematuhinya dan dapat pula mengasah kenyakinan akan kemampuan yang dimilikinya. Peserta didik yang memiliki self-efficacy yang tinngi tentunya memiliki kedisiplinan belajar yang tinggi pula dan memiliki kesadaran yang tinggi akan tujuan belajar yang dimilikinya selalu mengikuti proses pembelajaran dengan seksama dan berhasil akan tujuan belajarnya.

Adapun survey awal yang didapat dari observasi secara langsung pada peserta didik Madrasah Tsanawiyah (MTs) Ummul 
Quro Al-islami Banyusuci Leuwimekar Leuwiliang Bogor saat proses kegiatan belajar mengajar berlangsung maka didapatkan data-data, sebagai berikut:

1. Peserta didik tidak mengerjakan tugas yang diberikan guru.

2. Peserta didik tidak membawa buku pelajaran saat kegiatan belajar mengajar berlangsung.

3. Peserta didik tidak membawa buku sesuai dengan jadwal yang telah ditentukan.

4. Peserta didik tidur saat proses pembelajaran berlangsung.

5. Peserta didik keluar kelas untuk kekamar mandi, duduk-duduk dan lain sebagainya.

6. Peserta didik tidak mendengarkan penjelasan guru dan berdiskusi dengan temannya.

7. Peserta didik izin pulang melebihi batas waktu sehingga tertinggal materi pembelajaran di kelas.

8. Peserta didik tidak menjalani hukuman dari guru ketika mereka melakukan kesalahan.

Berdasarkan hasil survei pendahuluan dengan menggunakan angket pendahuluan untuk mengukur self-efficacy yang diuji cobakan pada peserta didik kelas VII dan kelas IX MTs Ummul Quro Al-islami, dan didapatkan hasil bahwa pada dasarnya peserta didik dapat menyelesaikan permasalahannya pada kondisi normal, dibuktikan pada pernyataan "Saya berusaha mengerjakan tugas dengan baik agar mendapatkan nilai yang tinggi" dengan ratarata 4,8 dan standar deviasi sebesar 0,4 , hal ini memiliki arti bahwa hampir seluruh peserta didik dapat mengerjakan tugas dengan baik untuk mendapatkan nilai yang tinggi. Dan peserta didik mulai mengalami kesulitan dalam mengatasi permasalahan yang dihadapinya yang dibuktikan pada pernyataan "Saya dapat mendapatkan nilai yang tinggi walaupun sedang terjadi masalah keluarga serta kurangnya dukungan dari keluarga". Dengan rata-rata sebesar 3.57 dan standar deviasi sebesar 0.97 hal ini memiliki makna bahwa tidak semua peserta didik bisa mendapatkan nilai yang tinggi ataupun menyelesaikan tugasnya dengan baik apabila sedang terjadi permasalahan kondisi lingkungannya. kemudian peserta didik benar-benar merasa kesulitan dalam mengalami permasalahannya apabila peserta didik dihadapkan dengan kondisi fisik maupun kondisi lingkungan yang kurang mendukung. Di buktikan pada pernyataan "saya mendapatkan prestasi yang lebih baik dibandingkan teman saya walaupun saya sering dibully" dengan rata-rata sebesar 1.1 yang berarti hanya sedikit dari pesertta didik yang mampu mendapat prstasi yang baik ketika dihadapkan dengan tekanan yang cukup berat yang dapat digambarkan pada jumlah rata-rata keseluruhan sebesar 3,66 serta simpangan baku keseluruhan diperoleh sebesar 0.50 atau 50\%. terlihat dari keseluruhan rata-rata dan standar deviasi yang diperoleh pada survei awal ini dapat disimpulkan kemampuan diri atau self-efficacy peserta didik masih tergolong rendah.

Dari data yang didapatkan bahwa permasalahan-permasalahan mengenai kedisiplinan belajar dan self-efficacy peserta didik MTs Ummul Quro Al-islami memiliki tingkat kedisiplinan peserta didik dan selfefficacy yang cukup rendah. 


\section{METODE}

\section{Desain Penelitian}

Jenis penelitian ini menggunakan pendekatan kuantitatif bersifat hubungan fungsional untuk mengetahui ada atau tidaknya pengaruh antara variabel bebas terhadap variabel terikat yaitu variabel kedisiplinan belajar terhadap variabel selfefficacy. Jenis paradigma menggunakan paradigma sederhana yang terdiri dari satu variabel independent dan satu variabel dependent.

\section{Tempat dan Waktu Penelitian}

Penelitian ini dilaksanakan di kelas I Progam Khusus (PK) di Madrasah Tsanawiyah Ummul Quro Al-islami yang beralamat di Jalan Moh Noh Noer Kampung Banyusuci RT 004/ RW 004 Desa Leuwimekar Kecamatan Leuwiliang Kabupaten Bogor Provinsi Jawa Barat Kode Pos 16640. pelaksanaan penelitian dimulai dari bulan Februari 2018 sampai dengan bulan Juni 2018.

\section{Variabel Penelitian}

Variabel penelitian adalah suatu atribut atau sifat atau nilai dari orang, objek atau kegiatan yang mempunyai variasi tertentu yang diterapkan oleh peneliti untuk dipelajari kemudian di tarik kesimpulannya (Sugiyono, 2014).

Dapat disimpulkan bahwa variabel penelitian ialah alat yang digunakan untuk melakukan penelitian yang mempunyai karektaristik yang berbeda-beda antara penelitian satu dengan penelitian yang lainnya.

Oleh karena itu variabel pada penelitian ini, ialah:

1. Variabel Terikat (Dependent Variabel). Variabel terikat ialah variabel yang keberadaannya dipengaruhi oleh variabel lainnya. Yang menjadi variabel terikat ialah self-efficacy.

2. Variabel Bebas (Independent Variabel). Variabel bebas ialah variabel yang keberadaannya mempengaruhi variabel lainnya. Yang menjadi variabel bebas ialah kedisiplinan belajar.

\section{Definisi Oprasional Variabel}

Kedisiplinan belajar ialah sikap patuh yang dimiliki oleh peserta didik dalam aturan mengikuti pelajaran, dalam penelitian ini definisi tentang kedisiplinan belajar ialah kesadaran dan kepatuhan akan peraturan yang berlaku dengan penuh tanggung jawab dan tampa adanya paksaan untuk mengahasilkan sebuah perubahan pada diri individu baik pengetahuan, keterampilan maupun prilaku dikesehariannya. peserta didik yang mempunyai kesadaran akan kedisiplinan belajar yang tinggi maka ia pun mempunyai kesadaran yang akan akan tujuan belajarnya.

Adapun indikator dari kedisiplinan belajar, yaitu:

1. Patuh akan peraturan

2. Kesadaran belajar

3. Bertanggung jawab

4. Pelatihan ketaatan

5. Kebiasaan menaati peraturan

Self-efficacy ialah kenyakinan diri yang dimiliki oleh individu, pada penelitian ini definisi self-efficacy adalah kenyakinan seorang induvidu terhadap kemampuan dirinya yang mengacu pada motivasi diri dengan penuh optimisme serta harapan untuk memecahkan permasalahan, melewati rintanagan dan menyelesaikan tugas tanpa mengeluh serta rasa putus asa agar tercapainya tujuan yang berpengaruh pada kehidupannya. Seorang individu yang memiliki self-efficacy yang tinggi akan berusaha untuk mencapai apa yang 
diinginkan tanpa adanya rasa takut maupun putus asa.

Adapun Indikator dari self-efficacy, yaitu:

1. Memiliki strategi

2. Dapat memotivasi diri

3. Percaya diri

4. Memiliki kenyakinan

5. Berfikir positif

6. Berjiwa optimis

\section{Populasi}

Populasi adalah objek atau subjek yang berada pada suatu wilayah generelisasi dan memenuhi syarat-syarat tertentu berkaitan dengan permasalahan atau objek-objek penelitian (Supardi, 2014). Dapat disimpulkan bahwa populasi ialah wilayah generelisasi yang terdiri dari subjek maupun objek memiliki karateristik yang dibutuhkan oleh peneliti yang berkaitan dengan permasalahan-permasalahan pada sebuah penelitian. Yang menjadi target populasi pada penelitian ini ialah seluruh peserta didik di kelas I PK di MTs Ummul Quro Al-islami yang terbagi menjadi tiga rombongan kelas yang digambarkan pada tabel 1.

Tabel 1 Rombongan Belajar Kelas I PK MTs Ummul Quro Al-islami

\begin{tabular}{ll}
\hline Kelas & Jumlah Peserta Didik \\
\hline I PK A & 37 Peserta didik \\
I PK B & 39 Peserta didik \\
I PK C & 39 Peserta didik \\
Total & 115 Peserta didik \\
\hline
\end{tabular}

Menurut tabel 1 Kelas I PK yang terdiri dari tiga rombongan kelas yaitu kelas I PK A dengan jumlah 37 peserta didik, kelas I PK B dengan jumlah 39 peserta didik dan I PK C dengan jumlah 39 peserta dengan jumlah keseluruhan yang menjadi populasi pada penelitian ini ialah 115 responden.

\section{Sampel}

Sampel adalah bagian dari jumlah dan karakteristik yang dimiliki oleh populasi tersebut (Sugiyono, 2016). Kesimpulannya sample adalah bagian dari populasi yang dijadikan fokus pada penelitian. Jumlah sample yang digunakan pada penelitian ini menggunan perhitungan rumus slovin dari 115 populasi kelas I PK dengan derajat kesalahan sebesar $5 \%$ didapatkan 89 peserta didik.

\section{Teknik Sampling}

Teknik sampling pada penelitian ini menggunakan teknik probality sampling. Probality sampling adalah teknik pengambilan sample yang memberi peluang yang sama bagi setiap anggota populasi untuk dijadikan anggota sample dengan menggunakan simple random sampling, dikatan simple (sederhana) karena pengambilan sample dilakukan secara acak tanpa mempehatikan strata pada populasi.

\section{Teknik Pengambilan Data}

Teknik pengambilan data digunakan untuk mempermudah peniliti dalam mengumpulkan data-data yang akan digunakan. pada penelitian ini menggunakan 3 teknik pengambilan data, yaitu:

1. Teknik Observasi

Proses pengumpulan data yang mengandalkan proses pengamatan dan ingatan data yang didapat dari kejadiankejadian ditempat yang akan diteliti.

2. Angket (kuesioner)

Proses pengumpulan data dengan memberian pernyataan-pernyataan atau pertanyaan-pertanyaan kepada subjek 
penelitian mengenai variabel yang akan diteliti.

3. Dokumentasi

Proses pengumpulan data yang didapat daari catatan, transkip, agenda, foro peristiwa dan lainya untuk keperluan suatu penelitian.

\section{Instrumen Penelitian}

Indikator pada setiap variabel akan dikembangkan menjadi instrumen penelitian, sebagai berikut.

1. Kedisiplinan belajar terbagi menjadi 5 indikator

a. Patuh peraturan

1) Patuh pada peraturan yang berlaku.

2) Menghargai dan menghormati kebijakan yang dibuat guru pada saat pembelajaran berlangsung.

3) Menjalani dan menaati peraturan.

b. Kesadaran dalam peraturan
1) Mengerjakan tugas yang diberikan saat proses pembelajaran.
2) Mengumpulkan dan menyelesaikan tugas tepat waktu.

3) Tidak tidur ataupun berdiskusi dengan teman ketika proses pembelajaran berlangsung.

c. Bertanggung jawab

1) Siap menjalani hukuman jika bersalah.

2) Jujur dalam mengerjakan tugas.

3) Mengakui kesalahan apabila melakukan hal yang salah.

d. Pelatihan ketaatan

1) Mengatur waktu belajar dengan kegiatan lainnya

2) Menyiapkan alat-alat sekolah.
3) Belajar sendiri sebulum proses pembelajaran berlangsung.

e. Kebiasaan menaati peraturan

1) Masuk kelas tepat waktu

2) Mendengarkan penjelasan guru.

3) Tidak keluar kelas ketika pembelajaran berlangsung.

4) Membawa buku pelajaran sesuai dengan jadwal.

5) Aktif masuk sekolah.

2. Self-efficacy, pada self-efficacy indikator yang diambi dari fungsi self-efficacy dan juga dimensi atau aspek-aspek selfefficacy itu sendiri.

a. Fungsi kognitif

1) Memiliki strategi untuk mencapai tujuan.

b. Fungsi motivasi

1) Dapat memotivasi dirinya sendiri.

2) Memiliki rasa kenyakinan diri.

3) Percaya akan kemampuan yang dia punya.

4) Memiliki pemikiran yang positif

c. Fungsi Selektif

1) Mampu mencari solusi akan permasalahannya.

d. Fungsi afektif

1) Mampu menahan tekanan dari luar dirinya maupun dari dalam dirinya yang dapat mengakibatkan stres.

e. Dimensi magnitude

1) Menganggap tugas yang sulit sebagai sebuah tantangan.

2) Yakin akan kemampuan diri.

3) Mengerjakan dan menyelesaikan tugas dengan baik dan rapih.

f. Dimensi generality

1) Mampu menyelesaikan tugas dengan baik walaupun 
dihadapkan dengan dua pekerjaan sekaligus.

g. Dimensi strenght

1) Yakin mampu mengerjakan berbagai tugas dengan dibarengi berbagai persoaan yang dihadapinya.

2) Mampu menyelesaikan tugasnya dengan baik walaupun dalam kondisi yang sangat tidak memungkinkan.

3) Memiliki jiwa yang optimis dan pantang menyerah.

\section{Perhitungan Skor}

Penelitian ini menggunakan perhitungan skor dengan bantuan skala likert. Skala likert ialah skala yang digunakan untuk mengukur sikap, pendapat, presepsi seseorang maupun sekolompok orang engenai fenoma sosial. Dalam penelitian ini, fenomena sosial ini telah ditentukan secara spesifik oleh peneliti yang selanjutnya disebut dengan variabel penelitian.

Dengan skala likert maka variabel yang akan diukur dijabarkan menjadi inikator variabel kemudian indikator tersebut dijadikan titik tolak untuk menyusun itemitem instrumen yang dapat berupa pertanyaan ataupun pertanyaan (Sugiyono, 2016). Perhitungan skor pada kedua variabel dijelaskan pada tabel 2 .

Tabel 2 Perhitungan Skor Kedua Variabel

\begin{tabular}{llll}
\hline \multirow{2}{*}{ No } & Katagori Jawaban & \multicolumn{2}{c}{ Pernyataan } \\
\cline { 3 - 4 } & + & - \\
\hline 1 & Sangat Setuju & 4 & 1 \\
2 & Setuju & 3 & 2 \\
3 & Tidak Setuju & 2 & 3 \\
4 & Sangat Tidak & 1 & 4 \\
& Setuju & & \\
\hline
\end{tabular}

Adapun menurut tabel 2 pertanyaan atau pernyataan yang bernilai positif yaitu pernyataan atau pertanyaan yang mendukung variabel, sedangkan yang bernilai negatif yaitu pernyataan dan pertanyaan yag menantang variabel.

\section{Uji Coba Instrumen}

Dalam sebuah penelitian data memiliki kedudukan yang tinggi karena data merupakan gambaran yang diteliti yang memiliki fungsi sebagai alat pembuktian hipotesis, Benar tidaknya data sangat menetukan bermutu atau tidaknya hasil penelitian, sedangkan benar tidaknya data tergantung dari benar tidaknya instrumen pengumpulan data sebuah instrumen dinyatakan baik sebagai alat ukur jika memiliki ciri-ciri yang shahih (valid) dan andal (reliabel) (Arikunto, 2013).

Pada uji coba instrumen menggunakan dua macam pengujian data, yaitu:

\section{Uji Validitas}

Pengujian validitas data pada penelitian ini menggunakan rumus Product Moment dari Karl Pearson berguna untuk menguji kevalidan suatu data.

Penelitian ini menggunakan uji validitas dengan menggunakan pendapat ahli (Expert Judgment), ahli dalam penelitian ini ialah Bapak Teguh Prasetyo, M. Pd. setelah itu intrumen dengan indikator-indikator yang akan diukur dan berlandasan teori tertentu selanjutnya dikonsultasikan kepada ahli. Setelah pengujian instrumen kepada ahli selesai lali dilanjutkan dengan uji coba instrumen atau validasi lapangan dengan subjek peserta didik kelas I PK. Uji coba instrumen dilakukan pada 18 orang peserta didik dari kelas I PK yang tidak dijadikan sample penelitian. Adapun kriteria pengujiannya dengan membandingkan 
$r_{\text {hitung }}<r_{\text {tabel }}$ maka butir intrumen yang dinyatakan tidak valid, yang berarti instrumen tersebut tidak dapat digunakan Tabel 3 Hasil Uji Coba Validitas

\begin{tabular}{|c|c|c|c|c|c|}
\hline Variabel & $\begin{array}{l}\text { Jumlah } \\
\text { Item } \\
\text { Semula }\end{array}$ & No Item Valid & $\begin{array}{l}\text { Jumlah } \\
\text { Item } \\
\text { Valid }\end{array}$ & No Item Gugur & $\begin{array}{l}\text { Jumlah } \\
\text { Item } \\
\text { Gugur }\end{array}$ \\
\hline $\begin{array}{l}\text { Kedisiplinan } \\
\text { Belajar peserta }\end{array}$ & 40 & $\begin{array}{l}1,2,4,5,7,8,11, \\
12,14,16,18,19, \\
20,21,25,28,33, \\
35,36,38\end{array}$ & 20 & $\begin{array}{l}3,6,9,10,13,15, \\
17,22,23,24,26, \\
27,29,30,31,32, \\
34,37,39,40\end{array}$ & 20 \\
\hline $\begin{array}{l}\text { Self-efficacy } \\
\text { peserta didik }\end{array}$ & 30 & $\begin{array}{l}1,4,5,7,9,12,13, \\
14,15,17,19,20, \\
21,22,23,24,25, \\
26,27,33,35,36\end{array}$ & 22 & $\begin{array}{l}2,3,6,8,10,11, \\
16,18,28,29,30, \\
31,32,34\end{array}$ & 14 \\
\hline
\end{tabular}

Pada tabel 3 di gambarkan untuk variabel kedisiplinan belajar dari 40 pernyataan yang diujikan diperoleh sebanyak 20 pernyataan yang valid dan untuk variabel self-efficacy dari 36 pernyataan yang di ujikan diperoleh sebanyak 22 pernyataan yang valid dan pernyataan yang valid tersebut dapat dilanjutkan untuk pengujian selanjutnya.

\section{Uji Reliabilitas}

Uji reliabilitas digunakan untuk menguji keajengan atau kosistensi sebuah instrumen, yang berupa pernyataan yang digunakan untuk penelitian, uji realibitas pada penelitian ini menggunakan teknik Cronbach Alpha. Hasil perhitungan realibitas (koefisien alpha) berkisar antara 0 sampai dengan 1 seperti yang digambarkan pada interprestasi yang menggunakan pedoman Riduan dan Akdon pada tabel 4. di dalam penetian ini. Hasil uji coba validitas dapat dilihat pada tabel 3 .
Tabel 4 Interprestasi Nilai r

\begin{tabular}{lccl}
\hline \multicolumn{2}{l}{ Besarnya $r$} & & Interprestasi \\
\hline Antara & 0.80 & sampai & Sangat Kuat \\
dengan 1.00 & & \\
Antara & 0.60 & sampai & Kuat \\
dengan 0.799 & & \\
Antara & 0.40 & samoai & Cukup Kuat \\
dengan & 0.599 & & \\
Antara & 0.20 & sampai & Rendah \\
dengan 0.399 & & \\
Antara & 0.00 & sampai & Sangat Rendah \\
dengan 0.199 & & \\
\hline
\end{tabular}

Semakin besar nilai koefisien reliabilitas maka semakin besar konsistensi atau kestabilan instrumen tersebut. Kepastian reliabel atau tidaknya ditentukan dengan membandingkan nilai $r_{\text {hitung }}$ dengan nilai $r_{\text {tabel }}$ untuk taraf kesalahan sebesar 5\% ataupun $1 \%$. Berdasarkan perbandingan dapat disimpulkan reliabel ada tidaknya sebuah instrumen kemudian dijadikan dasar untuk menentukan dapat atau tidak dapatnya instrumen itu digunakan dalam 
penelitian. Adapun hasil uji realibitas dapat dilihat pada tabel 5 .

Tabel 5 Hasil Uji Reabilitas Variabel

\begin{tabular}{lll}
\hline Variabel & $\begin{array}{l}\text { Koefisien } \\
\text { Alpha }\end{array}$ & Keterangan \\
\hline $\begin{array}{l}\text { Kedisiplinan } \\
\text { belajar peserta } \\
\text { didik }\end{array}$ & 0.929 & Sangar kuat \\
$\begin{array}{l}\text { Self-efficacy } \\
\text { peserta didik }\end{array}$ & 0.930 & Sangat kuat
\end{tabular}

Pada variabel kedisiplinan belajar maka disimpulkan koefisien realibitas variabel kedisiplinan belajar peserta didik sebesar 0.929 dengan katagori sangat kuat dan koefisien realibilitas variabel self-efficacy peserta didik sebesar 0.930 dengan katagori sangat kuat, dengan hal ini kedua variabel dapat digunakan untuk melakukan pengambilan data penelitian untuk langkah selanjutnya.

\section{Teknik Analisi Data}

\section{Analisis Inferensial}

Analisis inferensial, sering disebut juga statistik induktif atau statistik probalitas adalah statistik yang digunakan untuk menganalisa data sample dan hasilnya diberlakukan populasi statistik ini cocok digunakan bila sample diambil dari populasi yang jelas, dan teknik pengambilan sample dilakukan secara random (Sugiyono, 2016). Analisisi inferensial ialah analisis yang digunakan untuk menganilisis data yang samplenya diambil secara random.

\section{Uji Prasyarat Analisis}

Uji prasyarat analisis bertujuan untuk menguji apakah data yang telah terkumpul memenuhi persyaratan untuk dianalisatau tidak. Adapun uji prasyarat analisis meliputi uji normalitas dan juga uji linieritas.

\section{Uji normalitas}

Uji yang digunakan untuk mengetahui normal atau tidaknya suatu data. Pada penelitian ini pengujian normalitas menggunakan Kolmogrov-Smirnov yaitu teknik yang dillakukan apabila data yang akan diuji merupakan data tunggal, bukan data dalam distribusi frekuensi kelompok. Peneliti menggunakan bantuan SPSS 24 untuk memprediksi normal atau tidak.

\section{Uji linieritas}

Uji linieritas digunakan untuk mengetahui antara variabel bebas ataupun variabel terikat memiliki hubungan yang linier atau tudak. Pada pengujian linieritas peneliti menggunakan bantuan SPSS 24 untuk mengetahui antara variabel $\mathrm{X}$ dan $\mathrm{Y}$ linier atau tidak linier. Dengan keterangan:

1) Apabila nilai sig linierity $>0.05$ maka pengaruh antara variabel $\mathrm{X}$ terhadap $\mathrm{Y}$ adalah linier.

2) Apabila nilai sig. linierity $<0.05$ maka pengaruh antara variabel $\mathrm{X}$ dan variabel Y adalah tidak linier.

\section{Analisis Data}

Analisis data yang digunakan oleh peneliti antara lain, yaitu: korelasi Product Moment, persamaan regresi, dan koefisien determinasi.

\section{Korelasi Product Momen}

Digunakan untuk mengetahui hubungan antara variabel bebas (X) dan variabel terikat (Y) yaitu variabel kedisiplinan belajar peserta didik dan variabel selfefficacy peserta didik kelas I PK MTs Ummul Quro Al-islami. Dengan ketetapan jika $\mathrm{r}_{\text {hitung }}$ $>r_{\text {tabel }}$ maka terdapat korelasi akan tetapi apabila $r_{\text {hitung }}<r_{\text {tabel }}$ maka tidak terdapat korelasi antara kedua variabel. 


\section{Menetukan Persamaan Regresi}

Digunakan untuk melihat pengaruh kedisiplinan belajar peserta didik terhadap self-efficacy peserta didik kelas I PK MTs Ummul Quro Al-islami. Dengan menggunakan rumus regresi sederhana: $Y=a+b x$.

\section{Signifikansi Persamaan Regresi}

Pada uji persamaan regresi dengan kriteria pengujian analisis regresi adalah:

a. $\mathrm{H}_{0}$ diterima Jika $\mathrm{F}_{\text {hitung }}<\mathrm{F}_{\text {tabel. }}$

b. $\mathrm{H}_{0}$ ditolak jika $\mathrm{F}_{\text {hitung }}>\mathrm{F}_{\text {tabel. }}$.

\section{Menetukan Koefisien Determinasi}

Koefisien determinasi digunakan untuk mengetahui seberapa besar variabel bebas mempengaruhi variabel variabel terikat. Perhitungannya dibantu dengan SPSS 24.

\section{HASIL DAN PEMBAHASAN}

\section{Hasil}

Untuk memperoleh data mengenai kedisiplinan belajar dan self-efficacy yang dimiliki oleh peserta didik kelas I PK MTs Ummul Quro AL-islami. Peneliti memberi angket kepada peserta didik yang dijadikan sample penelitian yang berjumlah 81 peserta didik kelas I PK MTs Ummul Quro Al-islami. Adapun angket yang disebarkan terdiri dari 20 butir pernyataan yang mencakup tentang kedisiplinan belajar peserta didik dan 22 butir pernyataan yang mencakup self-efficacy peserta didik, dan setiap butirnya terdiri atas 4 alternatif jawaban yaitu sangat setuju (SS), setuju (S), tidak setuju (TS), sangat tidak setuju (STS) dengan skor penilaian 4, 3, 2, 1 untuk pernyataan yang berkonotasi positif, dan 1 , 2, 3, 4 untuk pernyataan yang berkonotasi negatif. Hasil data yang diperoleh peneliti dapat dilihat pada tabel 6

Tabel 6 Deskripsi Statistik

\begin{tabular}{lrrrrrrr}
\hline \multicolumn{1}{c}{ Variabel } & Mean & Median & Modus & Standar Deviasi & Max & Min & N \\
\hline $\begin{array}{l}\text { Kedisiplinan belajar peserta } \\
\text { didik }\end{array}$ & 67.53 & 67.00 & 60 & 6.758 & 80 & 52 & 20 \\
\begin{tabular}{l} 
Self-efficacy peserta didik \\
\hline
\end{tabular} & 71.21 & 70.00 & 70 & 7.247 & 88 & 58 & 22 \\
\hline
\end{tabular}

Dari analisis tabel 6 bahwa nilai kuantitatif variabel kedisiplinan belajar peserta didik yang terdiri dari 20 butir pernyataan diperoleh skor terendah sebesar 52 dengan skor tertinggi sebesar 80, skor rata-rata (mean) sebesar 67.53, median sebesar 67.70, modus sebesar 60 dan nilai standar deviasi sebesar 6.758 dan pada variabel self-efficacy peserta didik yang terdiridari 22 butir pernyataan diperoleh skor terendah sebesar 58, skor tertinggi sebesar 88, skor rata-rata (mean) sebesar 71.21, median sebesar 70.00, modus sebesar 70 dan nilai standae deviasi sebesar 7.247.

\section{Pengujian Prasyarat Analisis}

\section{Uji Normalitas}

Uji normalitas pada penelitian ini menggunakan Komogrov-smirnov Z dengan bantuan SPSS 24 yang dapat dilihat pada tabel 7. 
Tabel 7 Kolmogrov-Smirnov Z

Unstandardized

Residual

Kolmogrov-smirnov Z

Sig.

0.200

Jika nilai sig. $>0.05$ maka data berdistribusi normal tetapi jika nilai sig. < 0.05 maka data berdistribusi tidak normal. Dan dari analisa tabel 4 terlihat bahwa nilai sig. sebesar 0.200 maka itu berarti nilai sig $0.200>0.05$ dapat disipulkan bahwa data berdistribusi normal dan dapat dilanjutkan ke pengujian selanjutnya.

\section{Uji Linieritas}

Uji linieritas pada suatu data berguna untuk melihat kedua data linier atau tidak hal ini dapat dilihat pada tabel 8 .

Tabel 8 Uji Linieritas

\begin{tabular}{lrc}
\hline & \multicolumn{1}{c}{ F } & Sig \\
\hline Linierity & 25.018 & 0.000 \\
Deviation from Linierity & 0.667 & 0.857 \\
\hline
\end{tabular}

Berdasarkan hasil analisa dari tabel 8 didapatkan nilai sig linierity $0.000<0.05$ dan dilihat dari deviation from linierity nilai $\mathrm{F}$ diperoleh nilai $\mathrm{F}_{\text {hitung }}=0.667$ dan diperoleh nilai $\mathrm{F}_{\text {tabel }}=1.754$ dapat disimpulkan bahwa $\mathrm{F}_{\text {hitung }}=0.667<\mathrm{F}_{\text {tabel }}=$ 1.754 yang berarti bahwa terdapat hubungan linier signifikan antara variabel kedisiplinan belajar (X) dan variabel selfefficacy $(\mathrm{Y})$.

\section{Pengujian Hipotesis}

\section{Korelasi Product Moment}

Korelasi product moment digunakan untuk mengetahui keberadaan hubungan antara variabel $(X)$ dengan variabel $(Y)$. Jika nilai $r_{\text {hitung }}>r_{\text {tabel }}$ maka terdapat korelasi antara kedua variabel akan tetapi apabila $r_{\text {hitung }}<$ rtabel maka tidak terdapat korelasi antara kedua variabel. Pada pengujian korelasi product moment dapat dilihat pada tabel 9.

Tabel 9 Korelasi Product Moment

\section{Correlations}

\begin{tabular}{|c|c|c|c|}
\hline & & $\begin{array}{l}\text { Kedisiplinan } \\
\text { Belajar }\end{array}$ & $\begin{array}{l}\text { Self- } \\
\text { efficacy }\end{array}$ \\
\hline Kedisiplinan & Pearson & 1 & $.668^{* *}$ \\
\hline \multirow[t]{6}{*}{ Belajar } & Correlation & & \\
\hline & $\begin{array}{l}\text { Sig. } \\
\text { tailed) }\end{array}$ & & .000 \\
\hline & $\mathrm{N}$ & 81 & 81 \\
\hline & $\begin{array}{l}\text { Pearson } \\
\text { Correlation }\end{array}$ & $.668^{* *}$ & 1 \\
\hline & $\begin{array}{l}\text { Sig. } \\
\text { tailed) }\end{array}$ & .000 & \\
\hline & $\mathrm{N}$ & 81 & 81 \\
\hline
\end{tabular}

Berdasarkan tabel 9 korelasi antara variabel kedisiplinan belajar (X) dengan selfefficacy $(\mathrm{Y})$ diperoleh nilai sebesar $\mathrm{r}_{\text {hitung }}=$ 0.668 dan untuk nilai 81 adalah 0.216 pada taraf signifikansi 5\%. Dengan demikian $r_{\text {hitung }}>r_{\text {tabel }}(0.668>0.216)$ hal ini berarti $\mathrm{H}_{0}$ ditolak yang artinya adanya korelasi yang signifikan antara variabel kedisiplinan belajar dan self-efficacy peserta didik.

Dan dapat pula dilihat pada tabel 10 interprestasi untuk pengukuran tingkat hubugan antara kedisiplinan belajar dengan self-efficacy peserta didik. Nilai $r=0.668$ yang terdapat diposisi $0.60 \quad-0.799$ menunjukan bahwa terdapat hubungan yang kuat antara variabel kedisiplinan belajar dengan variabel self-efficacy yang memiliki makna memiliki hubungan yang positif. 
Tabel 10 Pedoman untuk memberikan Interprestasi terhadap koefisien korelasi

\begin{tabular}{ll}
\hline Interval Koefisien & Tingkat Hubungan \\
\hline $0,00-0.199$ & Sangat Rendah \\
$0.20-0.399$ & Rendah \\
$0.40-0.599$ & Sedang \\
$0.60-0.799$ & Kuat \\
$0.80-1.000$ & Sangat Kuat \\
\hline
\end{tabular}

\section{Menentukan Persamaan Regresi}

Persamaan regresi pada penelitian menggunakan persamaan regresi sederhana yang dapat dilihat pada tabel 11 .

Tabel 11 Koefisiensi

\begin{tabular}{llll}
\hline \multicolumn{1}{c}{ Model } & \multicolumn{1}{c}{ B } & \multicolumn{1}{c}{ T } & \multicolumn{1}{c}{ Sig. } \\
\hline (Constan) & 22.586 & 371 & 0.000 \\
Kedisiplinan & 0.717 & 7.971 & 0.000 \\
belajar & & & \\
peserta & & & \\
didik & & & \\
\hline
\end{tabular}

Berdasarkan tabel 11 nilai konstantan $(a)$ sebesar 22.586 dan nilai konstanta $(b)$ 0.717. maka persamaan reresi $Y=22.856=$ $0.717 \mathrm{X}$, ini berarti bila nilai kedisiplinan belajarbertambah 1 maka nilai rata-rata self-efficacy peserta didik akan bertambah 0.717 . Dan nilai $(b)$ pada perhitungan regresi di atas bernilai positif maka hubungan antara kedisiplinan belajar dengan self-efficacy peserta didik adalah berbading lurus yang artinnya jika kedisiplinan belajar baik maka self-efficacy peserta didik juga meningkat.

\section{Signifikansi Persamaan Regresi}

Pada signifikansi persamaan regresi dengan kriteria pengujian analisis uji regresi adalah $\mathrm{H}_{0}$ diterima jika $\mathrm{F}_{\text {hitung }}>\mathrm{F}_{\text {tabel }}$ dan $\mathrm{H}_{0}$ ditolak jika $F_{\text {hitung }}>F_{\text {tabel. }}$ maka pengujian sinifikansi persamaan regresi dapat dilihat dari tabel 12.

Tabel 12 Anova

\begin{tabular}{lrcc}
\hline \multicolumn{1}{c}{ Model } & Df & F & Sig \\
\hline Regression & 1 & 63.532 & .000 \\
Ressidual & 79 & & \\
\hline
\end{tabular}

Berdasarkan tabel 12 didapatan nilai $F_{\text {hitung }}=63.532$ dan nilai $F_{\text {tabel }}$ dengan dfreg = $1 \mathrm{dfres}=79$ adalah 3.96 pada taraf signifikansi $5 \%$ maka didapatkan $\mathrm{F}_{\text {hitung }}>$ $\mathrm{F}_{\text {tabel }}(63.532>3.96)$ dengan demikian $\mathrm{H}_{0}$ ditolak yang berarti terdapat pengaruh yang signifikan antara kedisiplinan belajar dengan self-efficacy peserta didik.

\section{Menentukan Koefisien Determinasi}

Koefisien determinasi digunakan untuk melihat seberapa besar variabel kedisiplinan belajar mempengaruhi variabel self-efficacy peserta didik yang dapat dilihat pada tabel 13.

Tabel 13 Koefisien Determinasi

\begin{tabular}{lrr}
\hline $\mathrm{R}$ & $\mathrm{R}^{2}$ & \multicolumn{1}{c}{ Ajusted $\mathrm{R}^{2}$} \\
\hline 0.668 & 0.446 & 0.439 \\
\hline
\end{tabular}

Hasil koefisiensi determinasi dari tabel 13 yaitu $\mathrm{R}^{2}$ adalah 0.446 yang menunjukan adanya $44.6 \%$ adanya variabel kedisiplinan belajar peserta didik mempengaruhi selfefficacy peserta didik dan sisanya 55,64\% dipengaruhi oleh varibabel lainnya yang bukan dianalisa pada penelitian ini.

\section{Pembahasan}

Hasil penelitian dari data yang diperoleh dari judul penelitian pengaruh kedisiplinan belajar terhadap self-efficacy peserta didik kelas I PK MTs Ummul Quro AL-islami Leuwiliang Bogor. Didapatkan nilai rata-rata (mean) pada variabel kedisiplinan belajar 
67.53 dan pada variabel self-efficacy sebesar 71.21. Uji prasyarat untuk menganilisis data mengunakan uji normalitas dan uji linieritas. Hasil uji normalitas terihat pada nilai signifikansi 0.200 , maka Sig. $>0.05$ yaitu $0.200>0.05$ ini artinya data berdistribusi normal. Pada pengujian linieritas diperoleh Sig. Linearity $0.000<$ 0.05 dan dilihat dari deviation from linearity nilai $\mathrm{F}$ diperoleh nilai $\mathrm{F}_{\text {hitung }}=0.667<\mathrm{F}_{\text {tabel }}=$ 1.754 kesimpulannya $F_{\text {hitung }}=0.667<\mathrm{F}_{\text {tabel }}=$ 1.754 artinya terdapat hubungan yang linier secara signifikan antara variabel kedisiplinan belajar (X) dengan variabel selfefficacy $(\mathrm{Y})$ peserta didik.

Untuk pengujian hipotesis statistik yang menetukan korelasi Product Moment, persamaan regresi, siginifikansi persamaan regresi serta koefisien determinasi $\left(\mathrm{R}^{2}\right)$. Korelasi product momen diperoleh nilai sebesar $r_{\text {hitung }}=0.668$ dan $r_{\text {tabel }}=$ untuk 81 responden adalah 0.216 pada taraf signifikansi $5 \%$. dengan demikian $\mathrm{r}_{\text {hitung }}=$ $0.668>\mathrm{r}_{\text {tabel }}=0.216$ maka $\mathrm{H}_{0}$ ditolak yang artinya terdapat korelasi yang signifikan antara kedisiplinan belajar dengan selfefficacy peserta didik. Persamaan regesi diperoleh nilai konstanta (a) sebesar 22.856 dan nilai konstanta $(b)$ sebesar 0.717 maka persamaan regresi $\mathrm{Y}=22.856$, ini berarti bila nilai variabel kedisiplinan pesera didik bertambah 1 maka nilai rata-rat pada variabel self-efficacy akan bertambah 0.717. Dan nilai $b$ pada perhitungan regresi yang telah dibahas bernilai positif maka dapat dikatakan bahwa hubungan antara kedisiplinan belajar peserta didik dengan self-efficacy peserta didik adalah hubungan yang berbanding lurus artinya jika kedisiplinan belajar peserta didik baik maka self-efficacy peserta didik juga meningkat. Signifikansi persamaan regresi diperoleh nilai $F_{\text {hitung }}=63.535$ dan $F_{\text {tabel }}$ dengan dfreg 3.96 pada taraf signifikansi $5 \%$ dengan demikian $\mathrm{H}_{0}$ ditolak yang berarti terdapat pengaruh yang signifikan antara kedisiplinan peserta didik dengan selfefficacy peserta didik dikelas I PK MTs Ummul Quro Al-islami Leuwiliang Bogor. Berdasarkan perhitungan, diketahui nilai beta satu (b) sebesar 0.717 artinya setiap satu angka variabel X maka terjadi kenaikan sebesar 0.717 pada variabel (Y), maka dapat disimpulkan bahwa nilai pengaruh yang diberikan variabel (Y) kepada variabel (X) bersifat positif. Berdasarkan hasil persamaan regresi maka dapat diprediksi bahwa semakin baik kedisiplinan belajar peserta didik maka akan semakin baik pula self-effiacacy yang dimiliki oleh peserta didik. Penjabaran di atas menunjukan bahwa secara teoritis kedisiplinan belajar peserta didik mempunyai pengaruh terhadap self-efficacy peserta didik yang dibuktikan dari perhitungan persamaan regresi yang bersifat positif. Selain itu diketahui bahwa nilai sumbangan kedisiplinan belajar peserta didik terhadap self-efficacy peserta didik sebesar $44.6 \%$ dan sisanya $55.4 \%$ dipengaruhi oleh faktor yang lainnya yang bukan dianalisa pada penelitian ini. oleh karena itu dapat disimpulkan hasil penelitian ini mendukung teori yang dikemukakan sebelumnya yaitu adanya pengaru antra kedisiplinan belajar peserta didik terhadap self-efficacy peserta didik kelas I PK MTs Ummul Quro Al-islami.

\section{KESIMPULAN DAN IMPLIKASI}

\section{Kesimpulan}

Berdasarkan hasil pengujian hipotesis membuktikan adanya pengaruh kedisiplinan belajar peserta didik terhadap self-efficacy peserta didik. Adapun hasil pengujian dengan menggunakan pengujian korelasi product moment, korelasi antara 
kedisiplinan belajar peserta didik (X) dengan self efficacy peserta didik (Y) diperoleh nilai sebesar $r_{\text {hitunh }}=0.668 \mathrm{dan}$ $r_{\text {tabel }}$ untuk 81 responden adalah 0.216 pada taraf signifikansi 5\%, dengan demikian $r_{\text {hitung }}>r_{\text {tabel }}(0.668>0.216)$ maka $\mathrm{H}_{0}$ ditolak yang artinya terdapat hubungan yang signifikan antara kedisiplinan belajar terhadap self-efficacy peserta didik. Dari perhitungan persamaan regresi didapatkan nilai konstanta (a) sebesar 22.856 dan nilai konstanta (b) sebesar 0.717 maka persamaan regresi $\mathrm{Y}=22.586+0.717 \mathrm{X}$, ini berarti bila nilai kedisiplinan peserta didik bertambah 1 maka nilai rata-rata selfefficacy 0.717. dan nilai (b) pada perhitungan persamaan regresi bernilai positif maka dapat dikatakan bahwa hubungan antara kedisiplinan belajar dengan self-efficacy adalah hubungan yang berbading lurus artinya jika kedisiplinan belajar peserta didik baik maka self-efficacy yang dimiliki peserta didik pun akan meningkat. Perhitungan persamaan signifikansi regresi didapatkan $F_{\text {hitung }}=$ 63.535 dan $F_{\text {tabel }}$ dengan dfreg $=1$ dan dfres = 79 adalah 3.96 pada taraf $5 \%$ dengan demikian $\mathrm{H}_{0}$ ditolak yang berarti terdapat pengaruh yang signifikan antara kedisiplinan belajar dan self-efficacy peserta didik. Dan penelitian ini mendapatkan sumbangan $\mathrm{R}^{2}=0.446$ yang menunjukan adanya $44.6 \%$ variabel kedisiplinan belajar peserta didik mempengaruhi variabel selfefficacy peserta didik, sisanya 55,4\% dipengaruhi oleh faktor lainnya yang bukan dianalisa pada penelitian ini. Dengan ini terbukti bahwa adanya pengaruh antara kedisiplinan belajar terhadap self-efficacy peserta didik di kelas I PK MTs Ummul Quro Al-islami.

\section{Implikasi}

Self-efficacy bagi peserta didik sangatlah penting adanya, oleh sebab itu guru sebaiknya dapat membantu peserta didik dalam memperoleh self-efficacy pada diri mereka, ada banyak cara yang dapat dilakukan oleh guru dalam menumbuhkan self-efficacy yang dimiliki oleh peserta didik salah satu caranya menegaskan kembali kedisiplinan yang berlaku di madrasah ataupun sekolah terutama kedisiplinan belajar. Karena dengan adanya kedisiplinan belajar yang teratur yang dilakukan secara terus-menerus dengan kesadaran yang tinggi merupakan salah satu faktor menumbuhkan self efficacy yang dimiliki oleh peserta didik itu sendiri. Dan dengan adanya self-efficacy yang tinggi pada diri peserta didik akan mendapat tuuan belajar yang diimpikannya dengan sangat mudah.

\section{DAFTAR PUSTAKA}

Arikunto, S. (2013). Prosedur Peneltian Suatu Pendekatan Praktik. Jakarta: Rineka Cipta.

Bandura, A. (1994). Self-efficacy in V.s Racmadhauran (Ed) encylopedia of Human Behaviour. New York: Academi Press. (Repainted in H. Friedman [Ed] Encylopedia of Mental Healt, San Diego: Academic Press.1998).

Munawaoh, S. (2017). Hubungan Minat dan Effikasi Diri dengan Kedisiplinan Belajar Pendidikan Kewarganegaraan Siswa Kelas IV Sekolah Dasar Negri Sekecamatan Pengasih Kabupaten Kulon Progo Daerah Istimewa Yogyakarta. Skripsi: Universitas Negri Yogyakarta.

Sugiyono. (2014). Metode Penelitian Kombinasi (MIxed Menthod). Bandung: Alfabeta. 
Sugiyono. (2016). Metode Penelitian Supardi. (2014). Aplikasi Statistik dam Kuantitatif, Kualitatif dan R\&D. Bandung: Alfabeta Penelitian Konsep Statistika yang Lebih Komprehensif. Jakarta Selatan: Change Publication. 